\title{
A Fiscal Price Tag for International Reserves
}

\author{
David Hauner
}




\title{
IMF Working Paper
}

Fiscal Affairs Department

\section{A Fiscal Price Tag for International Reserves}

\author{
Prepared by David Hauner ${ }^{1}$
}

Authorized for distribution by Manmohan S. Kumar

April 2005

\begin{abstract}
This Working Paper should not be reported as representing the views of the IMF. The views expressed in this Working Paper are those of the author(s) and do not necessarily represent those of the IMF or IMF policy. Working Papers describe research in progress by the author(s) and are published to elicit comments and to further debate.

This paper examines the (quasi-)fiscal impact of the (opportunity) cost of international reserves. It proposes a conceptual framework, with particular emphasis on two hitherto somewhat neglected aspects: a more appropriate measure of gross opportunity cost, and potential savings from lower external debt spreads that countries "buy" by holding reserves. The framework is then applied to 100 countries over 1990-2004. The results suggest that a turning point has been reached in recent years: while most countries made money on their reserves during 1990-2001, most have been losing money during 2002-04.
\end{abstract}

JEL Classification Numbers: F3, H54

Keywords: International reserves, opportunity cost, external debt, yield spreads

Author(s) E-Mail Address: dhauner@imf.org

\footnotetext{
${ }^{1}$ Thanks are due to Stephan Danninger, Mark De Broeck, Jorge Canales Kriljenko, and Manmohan S. Kumar for helpful comments, and to Martin Edmonds for providing the EMBI Global data. Naturally, any errors in the paper are the author's sole responsibility.
} 


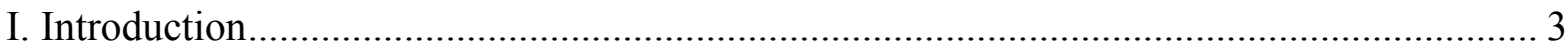

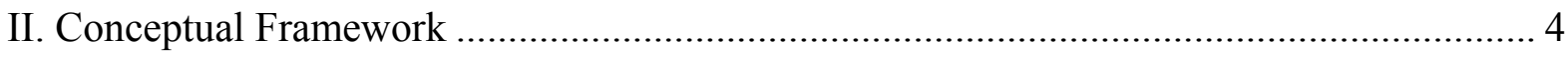

III. The (Opportunity) Cost of Reserves in a Hundred Countries ........................................ 7

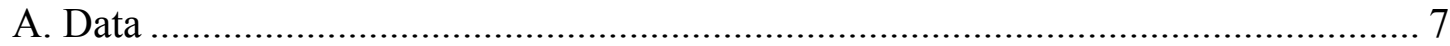

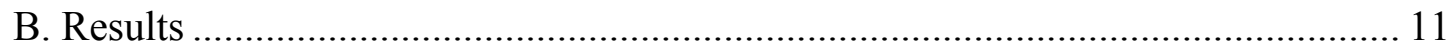

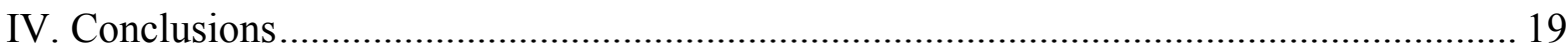

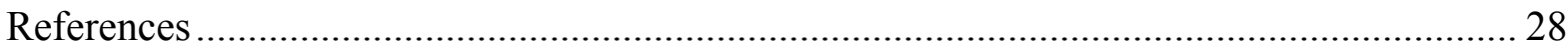

Boxes

1. Estimating the Spreads/Reserves Elasticity ........................................................... 9

2. How Robust Are the Results Against Changes in the Underlying Assumptions?............. 18

Tables

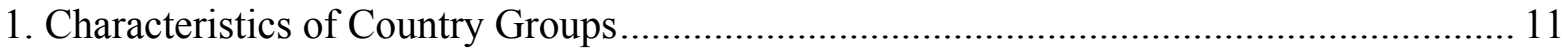

Figures

1. Measures of International Reserve Holdings, 1990-2004 ........................................... 12

2. The Opportunity Cost of International Reserves, 1990-2004 _..................................... 13

3. The Benefit from International Reserves, 1990-2004 .................................................. 14

4. Net (Opportunity) Cost of International Reserves, 1990-2004 ..................................... 15

Appendix Tables

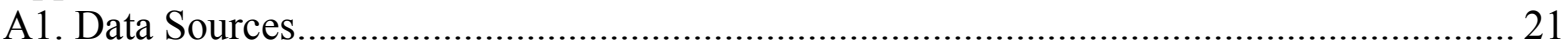

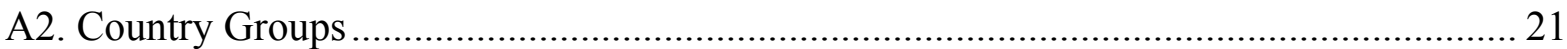

A3. Reserves in Percent of GDP .................................................................................... 22

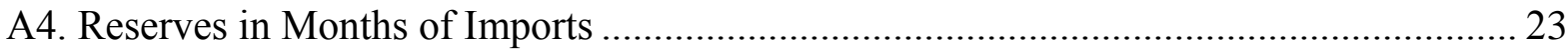

Appendix Figures

A1. Spreads and Reserves, 1998-2004 ........................................................................ 24

A2. Fits for Spread/Reserves Regression Controlling for the EMBI Global....................... 26 


\section{INTRODUCTION}

The vast accumulation of international reserves by a number of countries, particularly since the late 1990s, has revived interest in reserves-related issues. Research has focused mainly on explaining the demand for reserves, the assessment of reserve adequacy, and the reservesexchange rate nexus. ${ }^{2}$ The potentially substantial (quasi-)fiscal effects of holding international reserves, however, has so far been sidelined.

This paper examines the (quasi-)fiscal effects of holding international reserves. Reserves have a fiscal opportunity cost because they could alternatively be used to finance public capital expenditure or to pay down external debt and reduce the interest bill. In addition, they create a benefit or loss through the financial return on reserves, a lower government interest bill if reserves and interest rate spreads are negatively correlated, and often a sterilization cost. Combined, these factors can have a substantial (quasi-)fiscal impact through interest expenditure, central bank profits, ${ }^{3}$ and - indirectly — a lack of funds for public investment. A number of apparent policy changes in 2004 and 2005 seem to suggest that the (quasi-)fiscal cost of holding reserves has indeed become a source of concern in many countries. ${ }^{4}$

The paper in Section II proposes a conceptual framework for the quantification of the net (opportunity) cost of a country's reserves, with particular emphasis on two hitherto somewhat neglected aspects: a more appropriate measure of gross opportunity cost, and potential savings from lower external debt spreads that countries "buy" by holding reserves. Then, in Section III, the framework is applied — as far as data availability permits - to estimate the (opportunity) cost of reserves for 100 countries over the period 1990-2004. Section IV offers conclusions.

The results suggest that a turning point has been reached during the past couple of years: while most countries made money on their reserves during 1990-2001, with an estimated median net benefit peaking at 1.1 percent of GDP in 1999, most of them have been losing money during 2002-04, with an estimated median net cost peaking at 0.4 percent of GDP in 2004. This change in fortunes was the net result of several drivers: on the cost side, rising reserve holdings drove up the forgone savings from external debt repayment, although declining interest rates worked in the opposite direction. On the benefit side, the revaluation gains/losses from the rise and fall of the U.S. dollar dominated the impact of the secular and cyclical movements in industrial country interest rates and the estimated savings from a lower

\footnotetext{
${ }^{2}$ See, for example, Bird and Rajan (2003), Edison (2003), Flood and Marion (2002), IMF (2004a), and Lee (2004).

${ }^{3}$ For example, the European Central Bank (ECB) wrote down its foreign exchange holdings by $€ 2.1$ billion in 2004 , contributing to an overall loss of $€ 1.6$ billion.

${ }^{4}$ India's government said in 2004 that it would invest the country's reserves partly in infrastructure (The Economist 11/4/04). A number of central banks, including those of China (Financial Times 11/24/04), Korea (Financial Times 2/23/05), and Russia (Financial Times 2/5/05), indicated (unofficially) their intention to reduce the U.S. dollar share in their reserves, or to increasingly invest in nongovernment securities (e.g., Austria, Korea, and Switzerland, Financial Times 2/25/05).
} 
yield spread on external debt. These global trends, however, mask differences between countries, as elaborated on in Section III.

Shortcomings, stemming from the elusiveness of some of the underlying concepts and data constraints, must be borne in mind when reading the results. Conceptual problems mainly concern the appropriate definition of the social return on public investment and of the spreads/reserves elasticity. Within the given conceptual framework, data constraints mainly concern the cost of sterilizations, the currency split of reserves, and the output/capital elasticity. With regard to sterilizations, it is important to remember that the cost can be significant, also relative to the components of the net (opportunity) cost estimated here. Generally, however, the conceptual problems are more worrying than the data constraints: while impact of the latter can at least be gauged by sensitivity tests within the given conceptual framework, the impact of the former could be assessed only by a number of different conceptual frameworks, something that is beyond the scope of this paper.

However, assuming the conceptual framework is "correct," sensitivity tests conducted within the given framework suggest that the results are sufficiently robust against changes in the underlying assumptions for general conclusions, although the findings for some individual countries may display higher sensitivities.

\section{Conceptual Framework}

The fiscal (opportunity) cost of holding reserves consists of (A) the forgone return from alternative uses (typically external debt repayment or public investment), minus (B) the financial return on the reserve assets, minus (C) the savings from a lower interest bill if higher reserves are associated with lower spreads, plus (D) the present cost of past sterilizations.

Formally, a country's (opportunity) $\operatorname{cost} C_{t}$ of holding international reserves $R_{t}$ in period $t$ is

$$
C_{t}\left(R_{t}\right)=\left(\max \left\{r_{t}^{e}, r_{t}^{k}\right\}-r_{t}^{\$}-d_{t}\right) R_{t}-\varphi_{t} D_{t} .
$$

The first term represents aforementioned (A) and (B), where $r_{t}^{e}$ is the average interest rate on the country's external debt, ${ }^{5} r_{t}^{k}$ is the social return on public capital formation, $r_{t}^{\$}$ is the foreign currency return on the reserve assets, and $d_{t}$ is the weighted depreciation rate of the domestic currency against the reserve currencies. ${ }^{6}$ The second term represents (C), where

\footnotetext{
${ }^{5}$ Note the implicit assumption made here that $r_{t}^{e}$ is independent of $R_{t}$. Retiring debt is obviously not an option for borrowed reserves. However, note that, as defined here, the opportunity cost of earned and borrowed reserves is the same: Borrowing externally and investing in reserves yields $r_{t}^{\mathrm{s}}+d_{t}-r_{t}^{e}$, while investing in capital formation yields $r_{t}^{k}-r_{t}^{e}$. The opportunity cost of investing external borrowing in reserves instead of in capital formation is $\left(r_{t}^{k}-r_{t}^{e}\right)-\left(r_{t}^{\varsigma}+d_{t}-r_{t}^{e}\right)=r_{t}^{k}-r_{t}^{\varsigma}-d_{t}$, the same as for holding earned reserves.

${ }^{6}$ Precisely, the revaluation gain in a year $t$ is calculated by $R_{t}\left(e_{t}^{e}-e_{t-1}^{e}\right)+\left(R_{t}-R_{t-1}\right)\left(e_{t}^{e}-e_{t}^{a}\right)$, where $R_{t}$ is the endperiod stock of reserves and $e_{t}^{e}$ and $e_{t}^{a}$ are the end-of-period and average-of-period exchange rate, respectively.
} 


$$
\varphi_{t}=f\left(R_{t}, X_{t}\right)
$$

is the reduction in the yield spread on the country's privately held external $\operatorname{debt} D_{t}$ "bought" by holding reserves $R_{t}$, and $X_{t}$ is a vector of other explanatory variables.

Ideally, the present cost of past sterilizations (D) has to be included in the calculation of the net (opportunity) cost of reserves. However, data constraints prevent its calculation here, as elaborated in Section III.A. The principle shall be sketched nevertheless ${ }^{7}$ (in the forwardlooking perspective, which is more intuitive): in theory, the cost a central bank incurs in a given period due to a sterilizing intervention in a past period is the differential between the interest on the domestic-currency securities issued and the domestic currency return on the international reserves. Formally, the expected present value of sterilizing an increase in reserves $\Delta R_{t}$ in period $t$ is

$$
E_{t} \sum_{j=1}^{\infty} I_{t, t+j}\left[r_{t+j}^{d} e_{t} \Delta R_{t}\right],
$$

where $r_{t+j}^{d}$ is the domestic interest rate, $e_{t}$ is the exchange rate, and

$$
I_{t, t+j}=\prod_{i=t+1}^{t+j} \frac{1}{1+i_{i}}
$$

is the appropriate discount factor to apply to future public sector surpluses.

While the measurement of most of the aforementioned variables is theoretically straightforward (notwithstanding data problems discussed later on), measurement of the social return on capital $\left(r_{t}^{k}\right)$ and the spreads/reserves elasticity $\left(\varphi_{t}\right)$ clearly is not. The respective approaches taken here are discussed subsequently.

\section{The social return on capital}

Measuring the social return on capital is riddled with methodological and data problems. ${ }^{8}$ Most papers touching on the opportunity cost of reserves thus make a "heroic assumption" (H.R. Heller) on the social return on capital. Heller (1966) assumes 5-10 percent; Frenkel and Jovanovic (1981), Flood and Marion (2002), and Edison (2003) assume that it equals some government bond yields. Edwards (1985), Landell-Mills (1989), and Bird and Rajan (2003) avoid the problem altogether by assuming that all opportunity cost comes from forgone debt repayment and ignoring potential other alternative uses of reserves; and Lee (2004) assumes that the opportunity cost equals the liquidity premium on the reserve asset.

\footnotetext{
${ }^{7}$ See, for example, Kletzer and Spiegel (2000) for a more detailed discussion.

${ }^{8}$ See IMF (2004b, pp. 32-36) for a concise account of the methodological difficulties, and a summary table of the findings of empirical studies.
} 
Here, another approach to the calculation of the social return on capital is proposed. Assume production in period $t$ is given by a Cobb-Douglas production function

$$
Y_{t}=K_{t}^{\mu}\left(A_{t} L_{t}\right)^{1-\mu}
$$

where $Y, K, A$, and $L$ are output, capital stock, technology, and labor, respectively, and $\mu<1$. The marginal return on capital is then $\mu$ times the inverse of the capital-output ratio; that is,

$$
k_{t}=\mu \frac{Y_{t}}{K_{t}},
$$

where $\mu$ is the elasticity of output, $Y_{t}$, to an increase in the capital stock, $K_{t}$. Say, $R_{t}$ is invested in the capital stock in period $t$. Now the social rate of return, $r_{t}^{k}$, can be defined as the "internal rate of return" that satisfies

$$
\sum_{s=t+1}^{\infty} \frac{k_{s}(1-d)^{s} R_{t}}{\left(1+r_{t}^{k}\right)^{s}}=R_{t},
$$

where $d$ is the annual depreciation rate. Augmenting the capital stock for the calculation of the marginal return $k_{s}$ by the investment $R_{t}$, equation (6) becomes

$$
k_{s}=\mu \frac{Y_{s}}{K_{s}+R_{t}(1-d)^{s}},
$$

where $K_{s}$ is now the future capital stock excluding the invested reserves, and where it is assumed that the investment is not large enough to affect trend output growth. Substituting equation (8) into equation (7) finally yields the formula to calculate the social rate of return $r_{t}^{k}$ on investing reserves $R_{t}$ in the capital stock,

$$
\sum_{s=t+1}^{\infty} \frac{\mu \frac{Y_{s}}{K_{s}+R_{t}(1-d)^{s}}(1-d)^{s} R_{t}}{\left(1+r_{t}^{k}\right)^{s}}=R_{t} .
$$

A final note of caution: remember that this formula imposes a Cobb-Douglas production function on the economy. This assumption is clearly debatable, as any other would be. However, as Box 2 elaborates, using "intuitive" social rates of return, instead of the conceptual framework proposed here, yields empirical results that are quite similar. 


\section{The spreads/reserves elasticity}

For the estimation of the incremental yield spread saving $\varphi_{t}$ from holding reserves, this paper follows the approach in Duffie and others (2003) by modeling the actual yield spread $\varphi_{t}^{a}$ as a linear ${ }^{9}$ function of reserves and a vector of other variables, $X_{t}$ :

$$
\varphi_{t}^{a}=\alpha+\beta R_{t}+\gamma X_{t}
$$

Therefore,

$$
\varphi_{t}=\varphi_{t}^{0}-\varphi_{t}^{a}=\left(\alpha+\beta \cdot 0+\gamma X_{t}\right)-\left(\alpha+\beta R_{t}+\gamma X_{t}\right)=-\beta R_{t},
$$

and equation (1) can be rewritten as

$$
C_{t}\left(R_{t}\right)=\left(\max \left\{r_{t}^{e}, r_{t}^{k}\right\}-r_{t}^{\$}-d_{t}-\beta D_{t}\right) R_{t} .
$$

\section{The (Opportunity) Cost OF Reserves in A Hundred Countries}

This section applies the framework developed in the preceding section to estimate the fiscal cost of reserves in the world's 100 largest economies ${ }^{10}$ (except the United States, the reserve "center") over the period 1990-2004. This time period is particularly interesting to study the (opportunity) cost of reserves: it covers a long period of appreciation and then marked depreciation of the world's leading reserve currency, the U.S. dollar, against most currencies; a secular decline of world interest rates; and unprecedented international reserve accumulation by many countries.

\section{A. Data}

Most data are from the IMF's International Financial Statistics (IFS) and the IMF's World Economic Outlook (WEO) database. Exceptions are data on bond spreads (JP Morgan Chase \& Co./Datastream) and debt (Global Development Finance and BIS' International Financial Statistics). Appendix Table A1 shows a detailed description of the data sources.

International reserves as defined here are gross reserves and include both foreign exchange and gold at market value. ${ }^{11}$ The currency composition of reserves is not public information for

\footnotetext{
${ }^{9}$ There would also be good arguments for a nonlinear specification, because the marginal effect of reserves on spreads might be different by level of reserves. For example, it might be infinite for very low reserve levels, but tiny for very high reserve levels. Empirically, however, non-linearity does not seem to be a problem. Introducing an intuitive non-linearity (assuming that only reserves above three months import cover have a downward effect on spreads) in the specification that includes reserves/GDP and the EMBI Composite leaves the results virtually unchanged, as indicated by the means $(0.45$ vs. 0.47$)$ and the correlation coefficient $(0.87)$ of the savings on the interest bill in percent of GDP calculated by the individual country coefficients for the EMBI Global countries.

${ }^{10}$ In 2004, at PPP-adjusted exchange rates according to the IMF WEO database.

${ }^{11}$ Reserves for the euro area countries do not include those held by the ECB.
} 
most countries. However, the Bank for International Settlements (BIS) and the IMF report the aggregate currency composition of global reserves. Here, it is assumed that the currency composition is the same for all countries and that all reserves are denominated either in U.S. dollars or euros (or the ECU basket). The split between these two currencies is calculated according to the proportion reported in the IMF Annual Report. ${ }^{12}$ It is assumed that all U.S. dollar and euro reserves are held in U.S. and German treasury bills, respectively.

The (physical) capital stock for 1990 is from Nehru and Dhareshvar (1995). ${ }^{13}$ For 19912004, it is estimated by the perpetual inventory method. Beyond 2004, the ratio of the capital stock to GDP is held constant. Given that the ratio is trending upward in all but the most advanced economies, this assumption results in an overestimate of the future social return of investment today. The depreciation rate has to be assumed, since data are scarce even for industrial countries. Here, 5 percent is used, based on data from the few countries reporting fixed capital consumption for the IFS $^{14}$ and OECD data on the capital scrapping rate. ${ }^{15}$

Estimates of the output/capital elasticity vary widely depending on the countries and methods used. ${ }^{16}$ Many studies do not find a significant elasticity at all. However, Khan and Kumar (1997) find a significant elasticity of about 0.3 for 1970-90, and Clements and others (2003) find an elasticity of about 0.2 for 1970-99, each of them examining the average elasticity of per capita GDP growth to public investment for a large number of developing countries. Based on these estimates, here, the upper bound of the forgone social return on public investment assumes an elasticity of 0.3 , and the lower bound an elasticity of 0.2 .

The spreads/reserves elasticity is estimated for a 34-country sample, as described in Box 1. For the countries in this sample, the individual estimates of the coefficients on reserves are used as far as these coefficients are significant at least at the 10 percent level (except for Argentina, the Dominican Republic, Ecuador, and Uruguay, whose coefficients are clearly crisis-distorted). For the other countries, the median estimates of the 34 countries are used. Upper and lower bounds of the elasticity are based on the coefficients from regressions that include reserves and reserves/GDP as regressors, respectively (plus the EMBI Global). The elasticity is assumed as constant, as the data series are too short for a dynamic specification of

\footnotetext{
${ }^{12}$ As an alternative way to guess the currency composition, Ben-Bassat and Gottlieb (1992) propose to use the import shares as proxies for the currency composition. However, this assumes that imports are invoiced in the exporter's own currency, which is realistic only for very few countries.

${ }^{13}$ The most widely used source for capital stock data, the Penn World Tables, covers only 65 countries, while Nehru and Dhareshvar (1995) cover 92 countries.

${ }^{14}$ Based on the capital stock data in Nehru and Dhareshvar (1995), fixed capital consumption for 1985-2002 implies an average depreciation rate of 5.2 percent for Australia, 5.5 percent for Canada, 4.6 percent for New Zealand, 5.0 percent for the United Kingdom, and 4.9 percent for the United States.

${ }^{15}$ Naturally, the assumed depreciation rate affects the estimated social return to capital. For example, using alternatively 4 percent instead of 5 percent increases the median return to 5.6 percent, while a depreciation rate of 6 percent lowers the median return to 4.9 percent (both under an assumed output/capital elasticity of 0.3 ).

${ }^{16}$ See IMF (2004b), pp. 32-36.
} 
the reserves-spreads relationship. The savings from the lower interest bill are then estimated based on a country's privately held public and publicly guaranteed debt, since interest rates on debt owed to official creditors are likely to be little influenced by credit risk.

\section{Box 1. Estimating the Spreads/Reserves Elasticity}

Spreads and reserves are highly negatively correlated in many countries, as the figure based on monthly observations of the spreads for the 34 EMBI Global countries over the period 1998-2004 shows. (See Figure A1 in the Appendix for scatter plots for the individual countries.)

Spreads/Reserves Correlations Coefficients for EMBI Global Countries

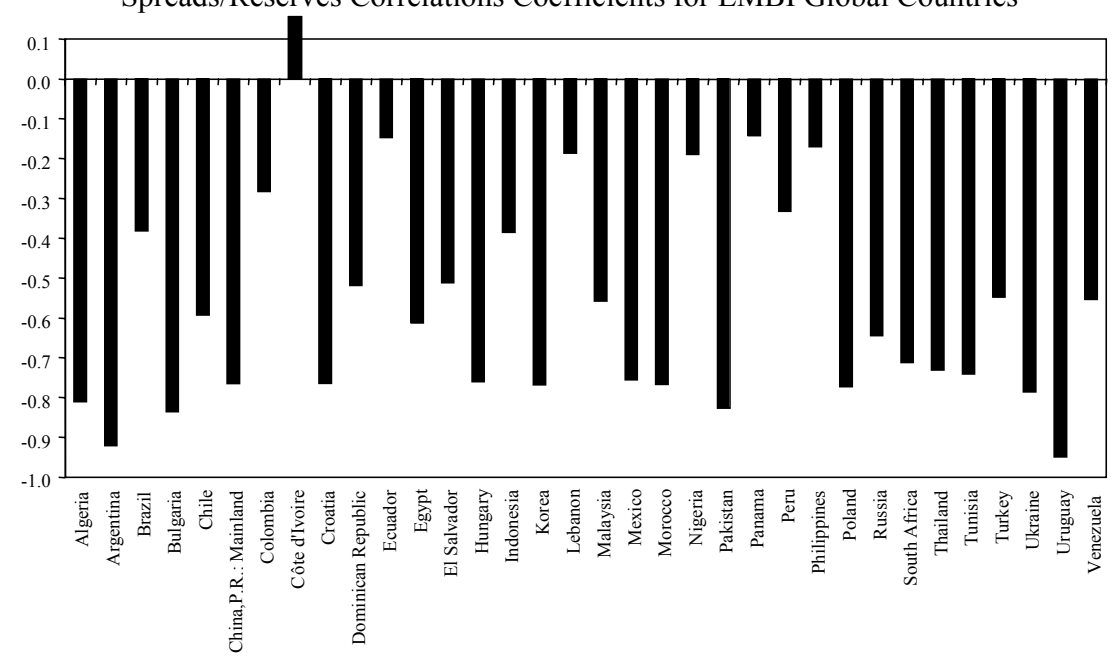

Sources: J.P. Morgan Chase \& Co., IFS, and author's calculations

Empirical examinations of the relationship between economic fundamentals and spreads often include international reserves as a measure of international liquidity, in nominal terms or scaled, for example, by amortization as in Ferrucci (2003). Other explanatory variables often included (see, e.g., Eichengreen and Mody, 1998) are external debt/GDP, debt service/exports, and some U.S. interest rate.

Here, the focus is on gauging how much countries potentially save on their interest bill by holding reserves. Therefore, a specification as simple as possible is adopted, allowing all factors that are secondary to reserves (e.g., the current account deficit) to directly impact the reserves coefficient. The simplest specification is to regress spreads on nominal reserves and a constant (e.g., as in Duffie and others, 2003). To control for market developments (general investor risk aversion in particular), the EMBI Composite is then included as an additional independent variable. ${ }^{17}$ Because it could be argued that investors care more about the reserves/GDP ratio than about nominal reserves, two more specifications (reserves/GDP and reserves/GDP plus EMBI Composite) are tried. To maximize observations, the estimation is based on the EMBI Global bond index spreads (monthly observations since the beginning of the index in January 1998 to October 2004). ${ }^{18}$ To remove country-specific effects, fixed-effect panel regressions are used. Monthly data for 34 countries make for 2,298 unbalanced observations during 1998-2004.

\footnotetext{
${ }^{17}$ There is multicollinearity between a country's reserves and the EMBI Composite to the extent that its reserves influence its spread, which then influences the index. This could be an issue for the larger countries.

${ }^{18}$ In the context of the argument made here, it would be more accurate to use primary market spreads, because this is the interest rate that matters most from the perspective of the issuer. However, secondary market spreads should be a valid proxy of primary market spreads for the basic question asked here about the relationship between spreads and reserves. Also, they are sufficiently correlated, as Eichengreen and Mody (1998) show.
} 


\section{Box 1. Estimating the Spreads/Reserves Elasticity (concluded)}

Goodness-of-Fit Measures of Various Specifications

\begin{tabular}{|c|c|c|c|c|}
\hline \multirow[b]{2}{*}{ Regressors } & \multicolumn{3}{|c|}{ Percent of 34 Country Coefficients on Reserves } & \multirow[b]{2}{*}{ R-squared } \\
\hline & Expected Sign & $\begin{array}{l}\text { Expected Sign } \\
\text { and Significant } \\
\text { at } 10 \text { percent }\end{array}$ & $\begin{array}{c}\text { Expected Sign } \\
\text { and Significant at } \\
1 \text { percent }\end{array}$ & \\
\hline Reserves & 97.1 & 85.3 & 79.4 & 0.80 \\
\hline Reserves, EMBI Global & 73.5 & 52.9 & 41.2 & 0.81 \\
\hline Reserves/GDP & 70.6 & 58.8 & 55.9 & 0.68 \\
\hline Reserves/GDP, EMBI Global & 76.5 & 61.8 & 55.9 & 0.69 \\
\hline
\end{tabular}

Source: Author's calculations.

The results suggest that reserves explain most of the variation in spreads. The table above shows some goodness-of-fit indicators of the four specifications (see also Figure A2 in the Appendix). The specification that only includes the dollar amount of reserves provides the best fit, with an R-squared of around 0.8 , the sign of the reserves coefficient as expected for nearly all countries, and 80 percent of the coefficients significant at the 1 percent level or better. However, there is autocorrelation in the residuals for many of the countries due to crises episodes not controlled for. Including year-dummies for the crises would remove the problem, but introduce an unwanted Impact of Reserves on Spreads in Various Cross-Section Specifications (predicted change in basis points for a US\$ 1 billion increase in reserves)

\begin{tabular}{lccc}
\hline \multicolumn{1}{c}{ Regressors } & Lower Quartile 1/ & Median 1/ & Upper Quartile 1/ \\
\hline Reserves & -119 & -44 & -18 \\
Reserves, EMBI Global & -103 & -29 & -9 \\
Reserves/GDP 2/ & -103 & -30 & -11 \\
Reserves/GDP, EMBI Global 2/ & -58 & -19 & -9 \\
\hline
\end{tabular}

Source: Author's calculations.

1/ Of countries with expected sign on reserves coefficient.

2/ Based on 2004 GDP.

element of

discretion in the estimation. Including other independent variables, such as the ratio of debt service to exports and the ratio of external debt to GDP does not substantially change the results. Results are also robust over time: changes in the sample length from 1998-2004 to 1999-2004 and 2000-04 leave the size of the coefficients and the significance levels virtually unchanged for the panel, although some countries show higher sensitivities.

The results indicate that increasing reserves by US $\$ 1$ billion lowers spreads by 44 basis points for the median country if the dollar amount of reserves is the only independent variable, and by 19 basis points if the EMBI Composite and GDP are controlled for - the other two specifications lie in between (see middle table). This translates into estimated savings on the interest bill (on public and publicly guaranteed debt owed to private creditors) of between 0.5 and 0.2 percent of GDP for the median country in 2003; the Estimated Savings from Lower Spreads, 2003

highest estimate for the first quartile country amounts to 0.7 percent of GDP (see bottom table).

(estimated savings on interest rate bill on public external debt in percent of GDP)

\begin{tabular}{lccc}
\hline \multicolumn{1}{c}{ Regressors } & First quartile 1/ & Median 1/ & Third quartile 1/ \\
\hline Reserves & -0.7 & -0.5 & -0.3 \\
Reserves, EMBI Global & -0.7 & -0.3 & -0.1 \\
Reserves/GDP & -0.6 & -0.4 & -0.1 \\
Reserves/GDP, EMBI Global & -0.4 & -0.2 & -0.1 \\
\hline
\end{tabular}

Source: Author's calculations.

$1 /$ Of countries with expected sign on reserve coefficient. 
To estimate the present cost of past sterilizations, data would be needed on the portfolio of securities the central bank is holding due to its sterilization operations, including details of the sterilization operations (including amounts, interest rates, and maturities). These data are not publicly available for most countries. Common rules of thumb (such as calculating sterilization from changes in the central bank's net foreign assets and reserve money), while being useful indicators of central bank intervention in a given year, are insufficient to calculate the cost of a sterilization accruing over a number of years. Thus, given these data constraints, the present cost of past sterilizations cannot be calculated here.

\section{B. Results}

The 100 countries are classified in six groups for presentational purposes. The groups combine a regional classification, income levels, and the importance of reserve holdings (Table 1). Appendix Table A2 shows the membership of the country groups. The results by individual country are available from the author upon request.

Table 1. Characteristics of Country Groups

\begin{tabular}{|c|c|c|c|c|c|c|c|}
\hline 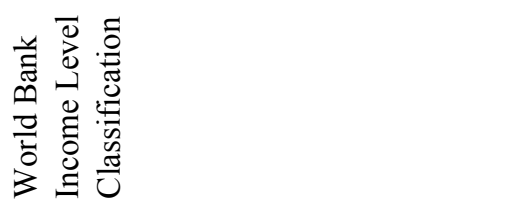 & 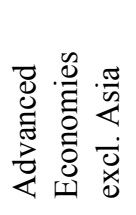 & $\begin{array}{l}0 \\
0 \\
0 \\
0 \\
0 \\
\frac{\pi}{\pi} \\
\frac{\pi}{4}\end{array}$ & 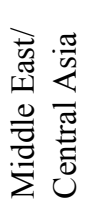 & 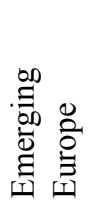 & 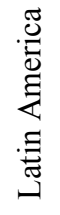 & 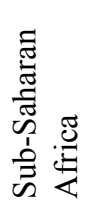 & 䒿 \\
\hline High & 21 & 5 & 2 & 0 & 0 & 0 & 28 \\
\hline Middle & 0 & 6 & 6 & 15 & 15 & 1 & 43 \\
\hline Low & 0 & 6 & 10 & 0 & 0 & 13 & 29 \\
\hline Total & 21 & 17 & 18 & 15 & 15 & 14 & 100 \\
\hline \multicolumn{8}{|l|}{ Percentage Share in World ... } \\
\hline ... 2004 Reserve Holdings & 21.8 & 56.9 & 6.0 & 7.9 & 6.4 & 0.9 & 100.0 \\
\hline .. 1990-2004 Reserve Accumulation & 4.8 & 75.1 & 6.7 & 4.2 & 8.1 & 1.1 & 100.0 \\
\hline
\end{tabular}

Sources: IMF (IFS), World Bank, and author's calculations.

The importance of reserve holdings, as measured by a number of indicators, has increased for all country groups - except Advanced Economies excl. Asia_-during 1990-2004, as Figure 1 shows:

- While nominal reserves remained approximately constant for the Advanced Economies excl. Asia, they have increased eight-fold for Asia Pacific. But also Emerging Europe experienced an impressive accumulation, albeit from very low levels. Furthermore, Latin America and Middle East/Central Asia approximately quadrupled their nominal reserves. And Sub-Saharan Africa also increased them substantially, albeit at relatively low levels. 

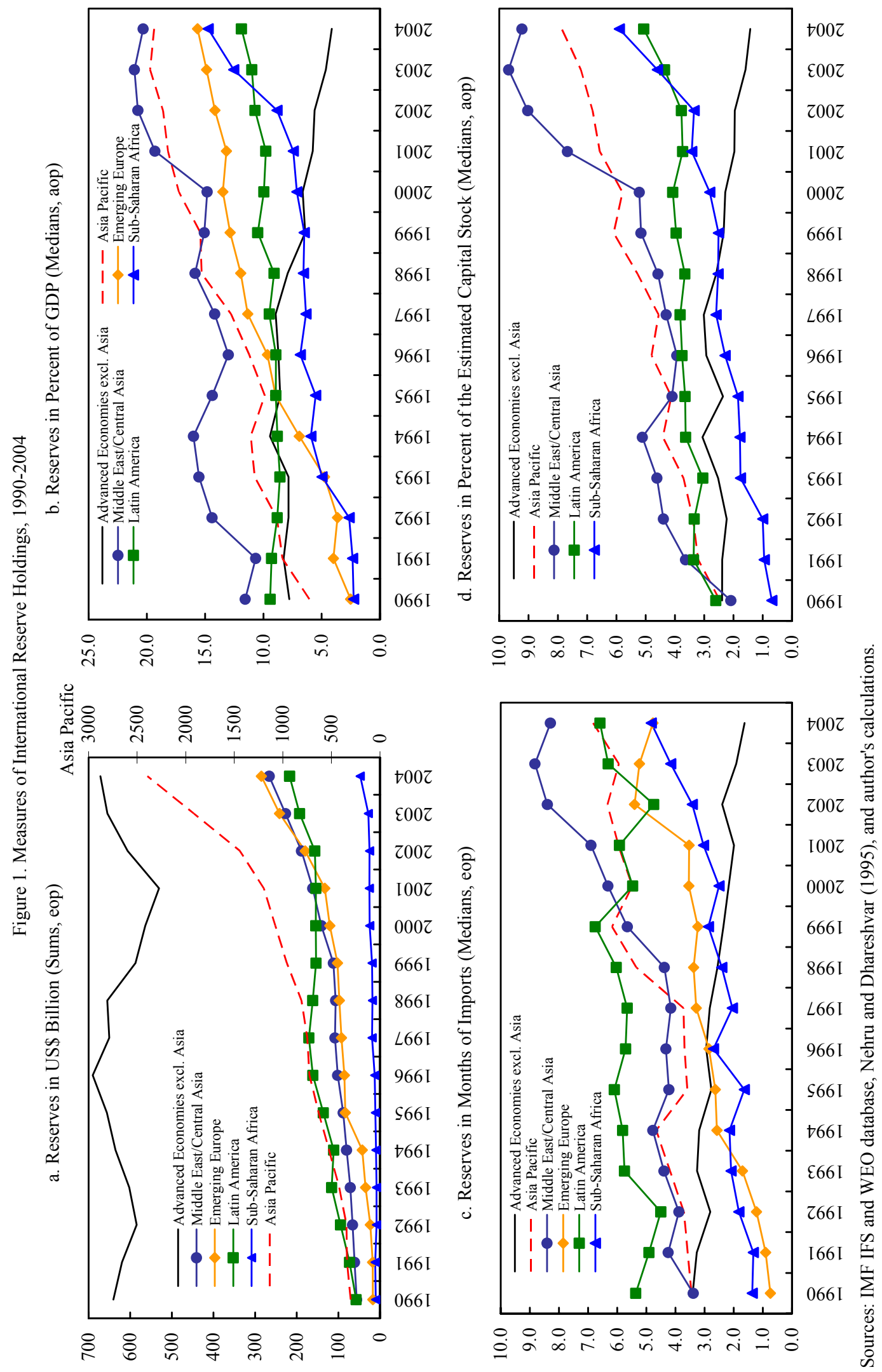


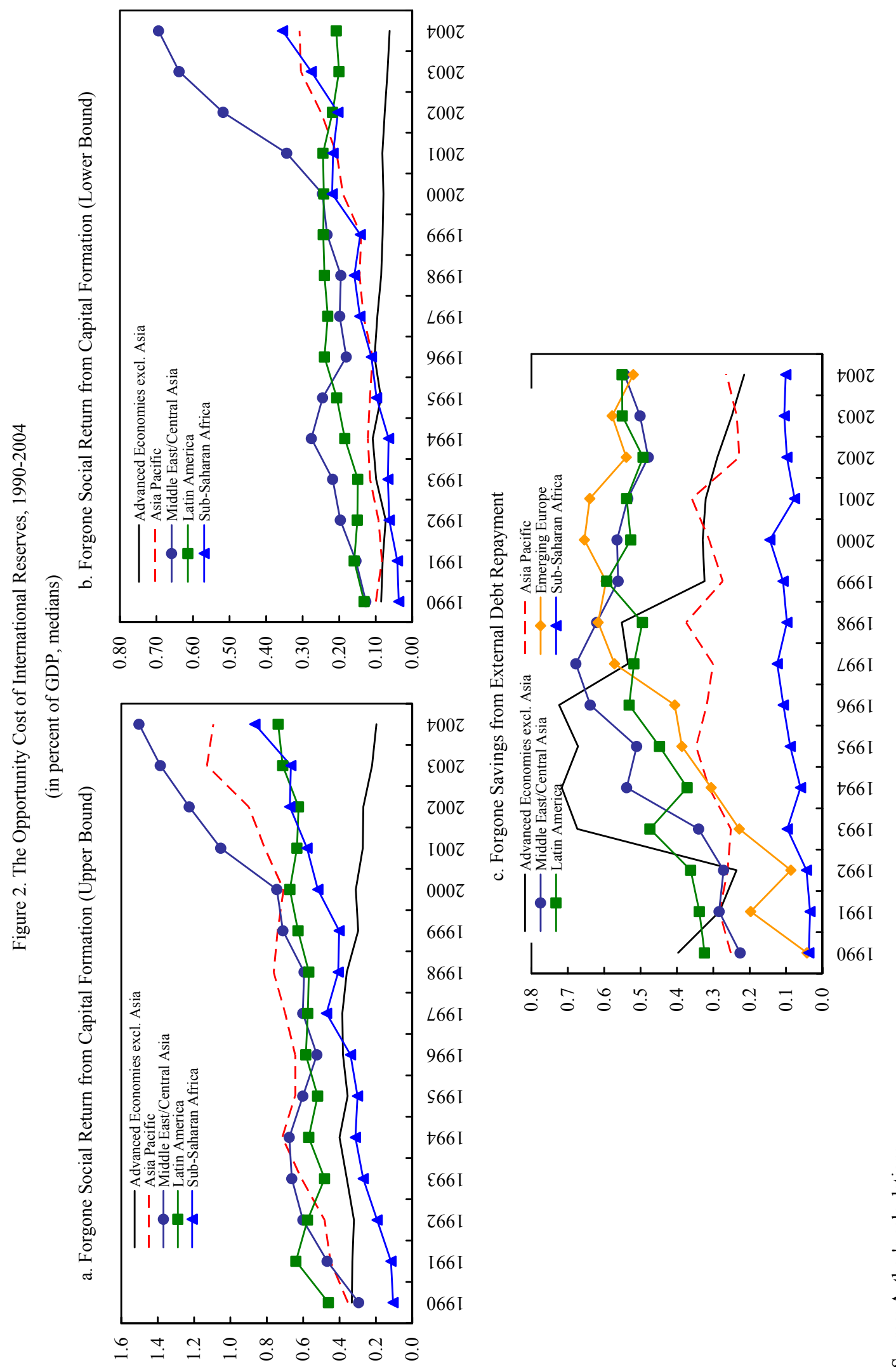



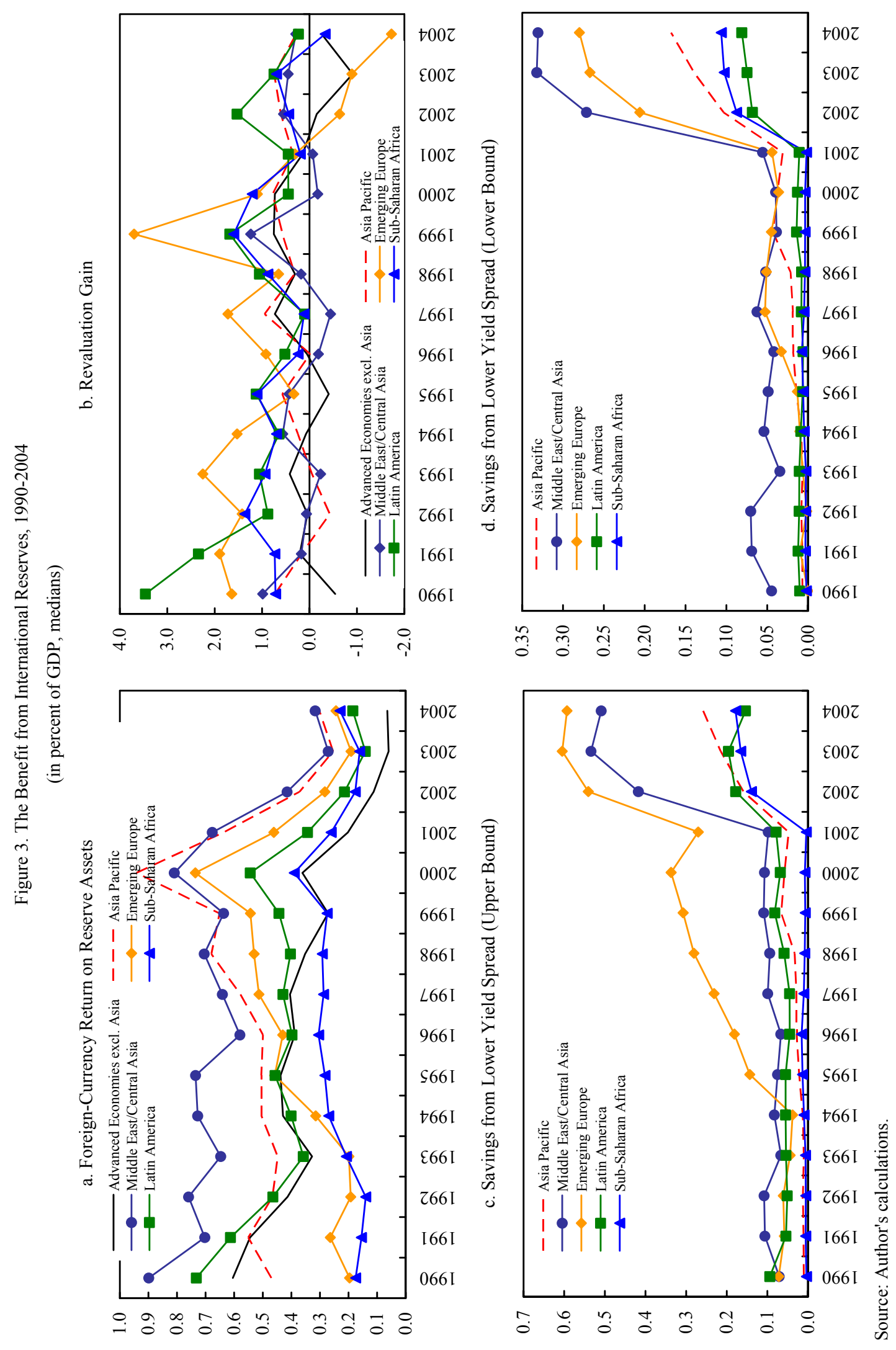


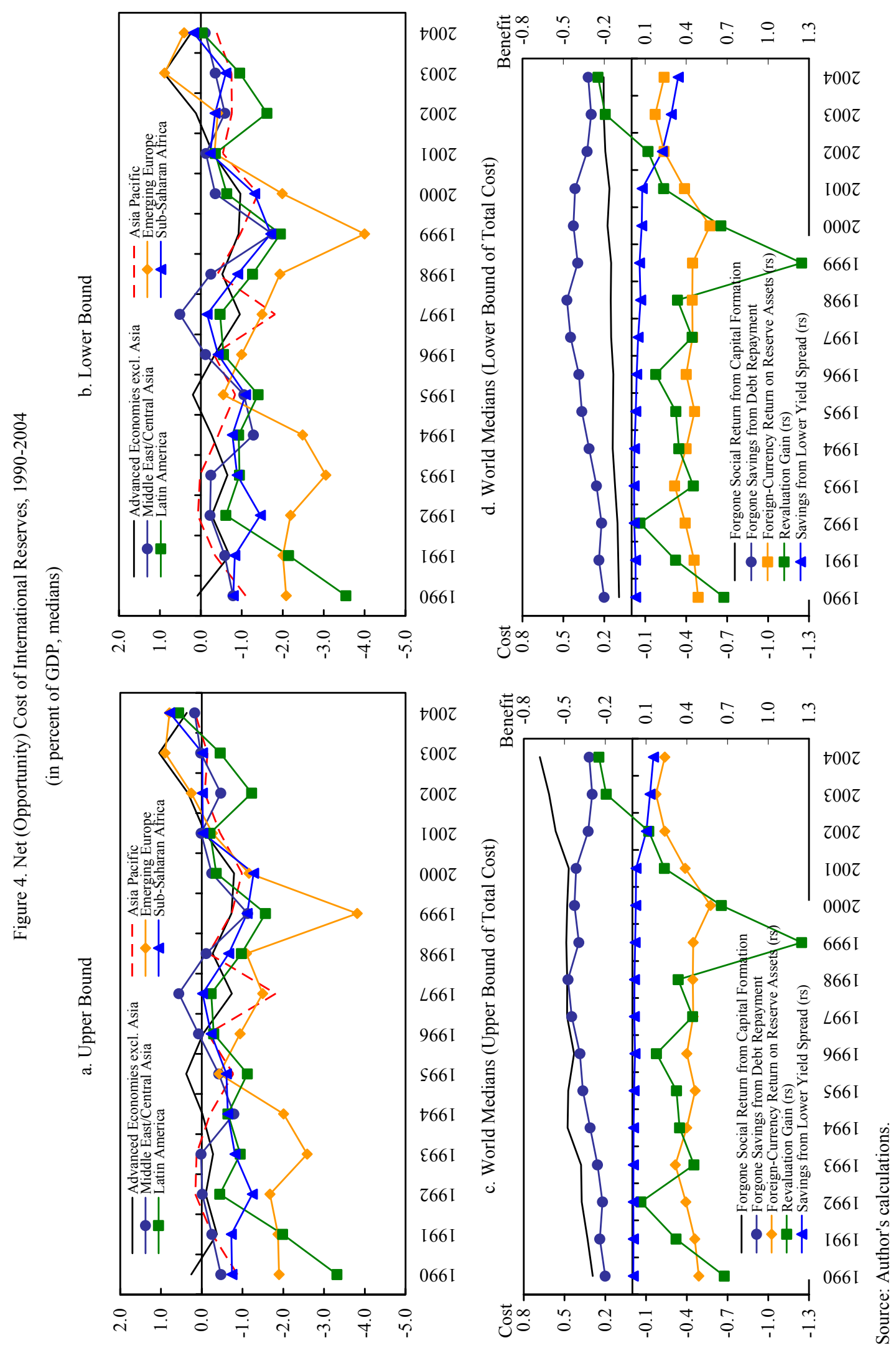


- While the traditional measures of reserves/GDP and reserves/imports largely reflect the nominal developments, some additional points arise from examining reserves in relative terms: (i) the Advanced Economies excl. Asia decreased their reserves relative to GDP and imports; (ii) in absolute terms, reserve accumulations has been even more impressive in Middle East/Central Asia than in Asia Pacific; (iii) in relative terms, Emerging Europe and Sub-Saharan Africa have seen the largest increase in their reserves; (iv) relative to GDP and imports, reserves in Latin America have increased only little; and (v) in all country groups except Advanced Economies excl. Asia, the median import cover was substantially above the rule of thumb of three months in 2004.

- Given the subject of this paper, it is useful to also look at the estimated reserves/capital stock ratio. The ratio increased most markedly in Middle East/Central Asia and Asia Pacific, to a median of 8-9 percent in 2004. In Latin America and Sub-Saharan Africa, the ratio rose less substantially, to about 5 percent in 2004. In the Advanced Economies excl. Asia, it declined to about 1.5 percent in 2004. ${ }^{19}$

The estimated opportunity cost of international reserves was about $0.5-0.6$ percent of GDP in Emerging Europe, Latin America, and Middle East/Central Asia, and about 0.20.3 percent of GDP in Asia Pacific and the Advanced Economies excl. Asia. External debt repayment (Figure 2) appears to be a more attractive option that public investment (Figure $2 \mathrm{a}-\mathrm{b}$ ) in most cases. While the estimation of the social return to capital is highly problematic (Section II), even its estimated upper bound is lower than the savings from repayment of external debt - if it is taken into account that the social return as calculated here (see equation (7)) is one-off, while the savings from lower external debt service accrue every future year. ${ }^{20}$ In Sub-Saharan Africa, however, public investment would likely yield a higher return than debt repayment, given a very low average interest rate due to the large share of concessional debt.

The estimated benefit from international reserves was substantial over the most of the 1990s, but declined significantly thereafter.

- $\quad$ The estimated foreign currency return (Figure 3a) on the reserve assets, obviously in swing with industrial country interest rates, is estimated to have peaked in 2000 at 0.9 percent of GDP in Asia Pacific, 0.8 percent in Middle East/Central Asia, 0.7 percent in Emerging Europe, 0.5 percent in Latin America, and 0.4 percent in Sub-Saharan Africa and the Advanced Economies excl. Asia. Since then, however, the decline in industrial country interest rates has brought down the estimated median

\footnotetext{
${ }^{19}$ No sufficient capital stock data is available for Emerging Europe.

${ }^{20}$ Note that this conclusion is even stronger given that the calculation of the social return on capital here ignores the discount factor and, therefore, tends to overestimate the present value relative to the savings on debt service.
} 
return to only $0.2-0.3$ percent of GDP in most regions, and even lower than that in the Advanced Economies excl. Asia.

- $\quad$ The estimated revaluation gain (Figure $3 b$ ) is the most important driver of the total net cost of international reserves, due to frequently large exchange rate swings. In Emerging Europe, at the extreme, the estimated median revaluation gain amounted to more than 2 percent of GDP in 1993 and 1999. Due to the secular appreciation of the U.S. dollar, the world median of the estimated revaluation gain was positive for all years during 1990-2002, peaking at 1.2 percent of GDP in 1999. (Obviously, the median gain was smaller in country groups with a large number of U.S. dollar pegs.) However, the decline in the U.S. dollar against many currencies in recent years has swung the revaluation gain into losses for many countries: the Advanced Economies excl. Asia and Emerging Europe appear to have been making losses on their reserves in each year during 2002-04, with a median loss of not less than 1.7 percent of GDP for 2004 estimated for Emerging Europe.

- $\quad$ The estimated savings from a lower interest rate spread on external debt (Figure $3 \mathrm{c}-\mathrm{d}$ ) appear to be relatively small in most countries, with a median upper bound of 0.2 percent of GDP in most country groups and years. However, in some countries (particularly in Emerging Europe and Middle East/Central Asia) that combine substantial private sector debt, large international reserves, and in some cases a high spread/reserves elasticity, ${ }^{21}$ estimated savings have increased to about $0.3-0.6$ percent of GDP in recent years.

In sum, the estimated net (opportunity) cost of international reserves suggests that most countries were making money on their reserves during 1990-2001 (Figure 4a-b). However, the Advanced Economies excl. Asia and Emerging Europe appear to have started losing money on their reserves in 2002 or 2003 (depending on whether one looks at the upper or lower bound of the overall estimate). In 2004, all country groups seem to have lost money on their reserves, with the medians of the estimated net cost ranging from -0.4 to 0.2 percent of GDP in Asia Pacific, over 0.0-0.2 percent of GDP in Middle East/Central Asia, ${ }^{22}$ and 0.0-0.6 percent of GDP in Latin America to 0.2-0.8 percent of GDP in the Advanced Economies excl. Asia, Emerging Europe, and Sub-Saharan Africa.

\footnotetext{
${ }^{21}$ Using a constant spread/reserves elasticity in a dynamic setting implies that an increase in reserves, holding debt constant, results in higher estimated savings on the interest bill.

${ }^{22}$ Many countries in these regions are less exposed to revaluation of their reserves due to their U.S. dollar pegs.
} 


\section{Box 2. How Robust Are the Results Against Changes in the Underlying Assumptions?}

Several assumptions or rough estimates have to be made to estimate the (opportunity) cost of reserves, most importantly on (i) the output/capital elasticity, (ii) the spreads/reserves elasticity, and (iii) the currency composition of reserve holdings. This box discusses the robustness of the results against changes in these three variables relative to the assumptions specified in Section III.A. The conclusion will be that reasonable changes in these three variables have only a limited impact on the results-with the exception of item (iii) in years of large changes in the exchange rates of the major reserve currencies.

(i) The output/capital elasticity feeds into the forgone return on capital formation through the social return on capital. Varying the elasticity within a reasonable range does not materially affect the estimated forgone return: comparing the results for the forgone social return on capital formation under the upper and lower bound assumptions in Figures $4 \mathrm{c}-\mathrm{d}$ shows that the difference for the world median is only $0.2-0.7$ percent of GDP; this is small, given the return is calculated as occurring one-off (see equations 5-9). To see why the difference is so small, remember that the forgone social return in percent of GDP is essentially equal to the rate of social return times the reserves/GDP ratio. While the social rate of return is substantially affected by a change in the capital/output elasticity (the median social rate of return for the 1,200 country years is 5.2 percent under an elasticity of 0.3 and 1.9 percent under an elasticity of 0.2 ), the reserves/GDP is in most countries reserves are not high enough to result in a substantial forgone social return. As an example, take the extremes of a social rate of return of 5 percent and 15 percent: based on the median 2004 reserves/GDP ratio of 15.4 percent, the difference in the oneoff forgone return on capital formation is only 1.5 percent of GDP. Also note that reserves, while being historically high, are still lower than annual gross capital formation in most countries.

(ii) The spreads/reserves elasticity determines, together with the privately held stock of public external debt, the estimated savings from a lower interest rate spread. Varying the elasticity within a reasonable range does not materially effect the estimated savings for most countries: comparing the results for the benefit from a lower interest rate spread under the upper and lower bound assumptions in Figures $4 \mathrm{c}-\mathrm{d}$ shows that the difference for the world median is below 0.2 percent of GDP for all years. To see why the difference is so small globally, note that only a few countries have substantial privately held external public debt relative to GDP. There are a couple of exceptions with somewhat more substantial differences, but only for 7 of 100 countries, the difference between the estimated upper and lower bounds of the savings from a lower interest rate spread is higher than 1 percent of GDP in 2004, and for only 1 country it is higher than 2 percent of GDP. The exceptions are all middle-income countries, because they are the ones with more substantial privately held public external debt.

(iii) The currency composition of reserves influences the foreign currency return on the reserve assets and the revaluation gain. The figure below shows the world medians of the foreign currency return plus the revaluation gain under five assumptions on the share of the U.S. dollar in reserves. (All assume that

Financial Return on Reserve Holdings (in percent of GDP)

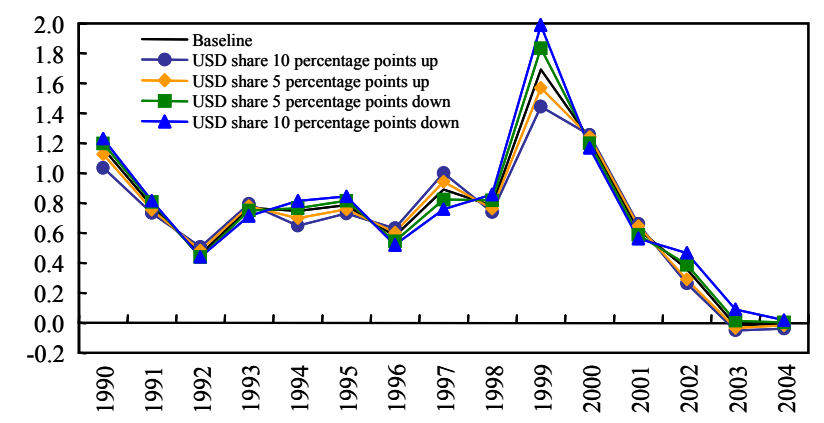

Source: Author's calculations. the U.S. dollar share is the same for all countries, which tends to overstate the differences in the results, because given a known world currency composition, higher U.S. dollar shares for some countries would require lower shares for other countries.) Only for 1999, when the U.S. dollar strongly appreciated against most currencies, does the assumption on the currency split make a more substantial difference ( 0.5 percent of GDP) for the world median when the assumed U.S. dollar share is varied for all countries by

10 percentage points up and down from the baseline assumption. For all other years, changes in the assumption on the currency distribution have only little impact on the estimated financial return. 
The estimated net benefit relative to GDP was generally lowest in the Advanced Economies and in Middle East/Central Asia. This reflected in the first case mainly the relatively low reserves/GDP ratio that limited the potential for financial returns relative to GDP; and in the second case, numerous U.S. dollar pegs limiting revaluation gains and a relatively high estimated forgone return on alternative uses, as discussed above. The estimated net benefit was generally highest in Emerging Europe and Latin America, reflecting relatively high estimated revaluation gains and relatively high estimated savings from lower spreads.

The most important and most volatile of the drivers of the estimated net (opportunity) cost of reserves over the period 1990-2004 was the estimated revaluation gain (Figure 4c-d). Its world median amounted to gains in all years during 1990-2000 - some of them large-but to a loss of 0.2 percent of GDP in both 2003 and 2004. Next in importance was the foreign currency return on the reserve assets, whose estimated world median was about 0.4-0.6 percent of GDP during 1990-2001, but fell to 0.2 percent of GDP during 2002-04. The forgone return on alternative uses was dominated by the estimated forgone savings from debt repayment, whose estimated world median amounted to 0.2-0.4 percent of GDP over the period 1990-2004. The forgone social return on capital formation was only important in the upper bound case (assuming a high output/capital elasticity), with about $0.3-0.7$ percent of GDP; in the lower bound case (assuming a low output/capital elasticity), it was negligible with only $0.1-0.2$ percent of GDP. The world median of the estimated savings from a lower yield spread was negligible during 1990-2001, but amounted to a more substantial 0.1-0.3 percent of GDP during 2002-04.

\section{Conclusions}

This paper proposed a framework for the quantification of the net (opportunity) cost of a country's international reserves. The framework was applied to estimate the components of the net (opportunity) cost of international reserves for 100 countries over the period 19902004.

The results suggest that a turning point has been reached. While countries were making money on their reserves during 1990-2001, with an estimated median net benefit peaking at 1.1 percent of GDP in 1999, they were losing money during 2002-04, with an estimated median net cost peaking at 0.4 percent of GDP in 2004. This change in fortunes was the net result of several drivers: on the cost side, rising reserve holdings drove up the forgone savings from external debt repayment, although declining interest rates worked in the opposite direction. On the benefit side, the revaluation gains/losses from the rise and fall of the U.S. dollar dominated the impact of secular and cyclical movements in industrial country interest rates, and the estimated savings from a lower yield spread on external debt.

Some shortcomings, stemming from the elusiveness of some of the underlying concepts and data constraints, must be born in mind when reading the results. Conceptual problems mainly concern the appropriate definition of the social return on public investment and of the spreads/reserves elasticity. Within the given conceptual framework, data constraints mainly concern the cost of sterilizations, the currency split of reserves, and the output/capital 
elasticity. With regard to sterilizations, it is important to remember that their cost can be significant, also relative to the components of the net (opportunity) cost estimated here. Generally, however, the conceptual problems are more worrying than the data constraints: while impact of the latter can at least be gauged by sensitivity tests within the given conceptual framework, the impact of the former could be assessed only by a number of different conceptual frameworks, something that is beyond the scope of this paper.

Assuming the conceptual framework is "correct," how robust are the results against changes in the underlying assumptions? The short answer is: sufficiently for general conclusions. Summarizing the points elaborated in Box 2: regarding the assumptions on the output/capital elasticity and the spreads/reserves elasticity, the paper works with lower and upper bounds; however, the differences between the overall upper and lower bound estimates turn out to be quite small. Regarding the assumption on the currency composition of reserves, the estimates remain fairly robust when the assumed currency composition of the reserves is varied within a reasonable range. Nevertheless, while the aforementioned assumptions do not materially affect the results on a global basis, they are likely to have a more substantial impact on the results in some individual countries.

Broad country coverage, as in this paper, comes at a cost: detail on individual country cases may get lost. Therefore, case studies of selected countries could be useful extensions of the global examination conducted here. This concerns particularly countries with above-par data on reserve management, which would be required for a reliable assessment of the potentially substantial cost of sterilization, and with public data on the currency composition of reserves.

What can policymakers draw from the results? Mainly that the findings here confirm conclusions many of them seem to have already made in recent months: because international reserves have reached unprecedented levels in many countries, interest rates are at long term lows, and the world's most important reserve currency has been depreciating on a broad basis, policies for reserve management are continuously being revisited - for example, many central banks are increasingly investing also in less liquid and longer-dated securities to increase returns on their reserves. ${ }^{23}$ Many central banks are also diversifying the currency composition of their reserves. Also in a broader sense, the social cost of reserves is coming under increased scrutiny in a number of countries, with the Indian government's plans to finance additional fiscal loosening for the sake of higher expenditure infrastructure by drawing down international reserves being the most prominent example. ${ }^{24}$

\footnotetext{
${ }^{23}$ See, for example, Financial Times 3/19/05.

${ }^{24}$ The Economist 11/4/04.
} 
Table A1. Data Sources

\begin{tabular}{|c|c|}
\hline Variable & Source (Series) \\
\hline Total reserves minus gold (eop) & $\begin{array}{l}\text { IFS (.1L.DZF...), gaps filled with } \\
\text { WEO (BRASS) }\end{array}$ \\
\hline Gold at market prices & IFS (.1AMSZF...) \\
\hline Share of US dollars in global reserves & IMF Annual Reports \\
\hline EMBI+ Global spread & JP Morgan Chase \& Co./Datastream \\
\hline Public and publicly guaranteed external debt stock & $\begin{array}{l}\text { GDF (DTDODDECTCD), gaps filled } \\
\text { with BIS (consolidated claims of } \\
\text { reporting banks on individual } \\
\text { countries/public sector) and BIS } \\
\text { (international debt securities by } \\
\text { nationality of issuer/governments) }\end{array}$ \\
\hline Public and publicly guaranteed external debt owed to private creditors & GDF (DTDODPRVTCD) \\
\hline Average interest rate on public external debt & $\begin{array}{l}\text { calculated GDF } \\
\text { (DTINTDECTCD)/GDF } \\
\text { (DTDODDECTCD), gaps filled with } \\
\text { WEO (GGD)/WEO (GGEI) }\end{array}$ \\
\hline Gross fixed capital formation, current prices & WEO (NFI) \\
\hline Capital stock & Nehru and Dhareshvar (1995) \\
\hline GDP at constant prices & WEO (NGDP_R) \\
\hline Nominal GDP in local currency & WEO (NGDP) \\
\hline Nominal GDP in US dollars & WEO (NGDPD) \\
\hline Imports of goods and services & WEO (BM) \\
\hline National currency per USD (aop) & WEO (ENDA) \\
\hline National currency per USD (eop) & IFS (..AE.ZF...) \\
\hline National Currency per ECU (eop) & IFS (..EB.ZF ...) \\
\hline National Currency per SDR (eop) & IFS (..AA.ZF...) \\
\hline Treasury bill rate (aop) & IFS (60C..ZF ...) \\
\hline
\end{tabular}

Source: Author. Notes: BIS ... BIS International Financial Statistics, GDF ... World Bank Global Development Finance, IFS ... IMF International Financial Statistics, WEO ... IMF World Economic Outlook Database.

Table A2. Country Groups

\begin{tabular}{|c|c|c|c|c|c|}
\hline $\begin{array}{l}\text { Advanced Economies } \\
\text { excl. Asia }\end{array}$ & Asia Pacific & Middle East/Central Asia & Emerging Europe & Latin America & Sub-Saharan Africa \\
\hline Australia & Bangladesh & Algeria & Belarus & Argentina & Angola \\
\hline Austria & Cambodia & Azerbaijan & Bulgaria & Bolivia & Cameroon \\
\hline Belgium & China & Egypt & Croatia & Brazil & Congo, Dem. Rep. of \\
\hline Canada & Hong Kong SAR & Iran, I.R. of & Czech Republic & Chile & Côte d'Ivoire \\
\hline Denmark & India & Jordan & Hungary & Colombia & Ethiopia \\
\hline Finland & Indonesia & Kazakhstan & Latvia & Costa Rica & Ghana \\
\hline France & Japan & Kuwait & Lithuania & Dominican Republic & Kenya \\
\hline Germany & Korea & Lebanon & Poland & Ecuador & Mozambique \\
\hline Greece & Malaysia & Libya & Romania & El Salvador & Nigeria \\
\hline Ireland & Myanmar & Morocco & Russia & Guatemala & South Africa \\
\hline Israel & Nepal & Oman & Serbia and Montenegro & Mexico & Sudan \\
\hline Italy & Philippines & Pakistan & Slovak Republic & Paraguay & Tanzania \\
\hline Luxembourg & Singapore & Saudi Arabia & Slovenia & Peru & Uganda \\
\hline Netherlands & Sri Lanka & Syrian Arab Republic & Turkey & Uruguay & Zimbabwe \\
\hline New Zealand & Taiwan Prov.of China & Tunisia & Ukraine & Venezuela & \\
\hline Norway & Thailand & Turkmenistan & & & \\
\hline Portugal & Vietnam & United Arab Emirates & & & \\
\hline Spain & & Uzbekistan & & & \\
\hline \multicolumn{6}{|l|}{ Sweden } \\
\hline \multicolumn{6}{|l|}{ Switzerland } \\
\hline United Kingdom & & & & & \\
\hline
\end{tabular}


Table A3. Reserves in Percent of GDP

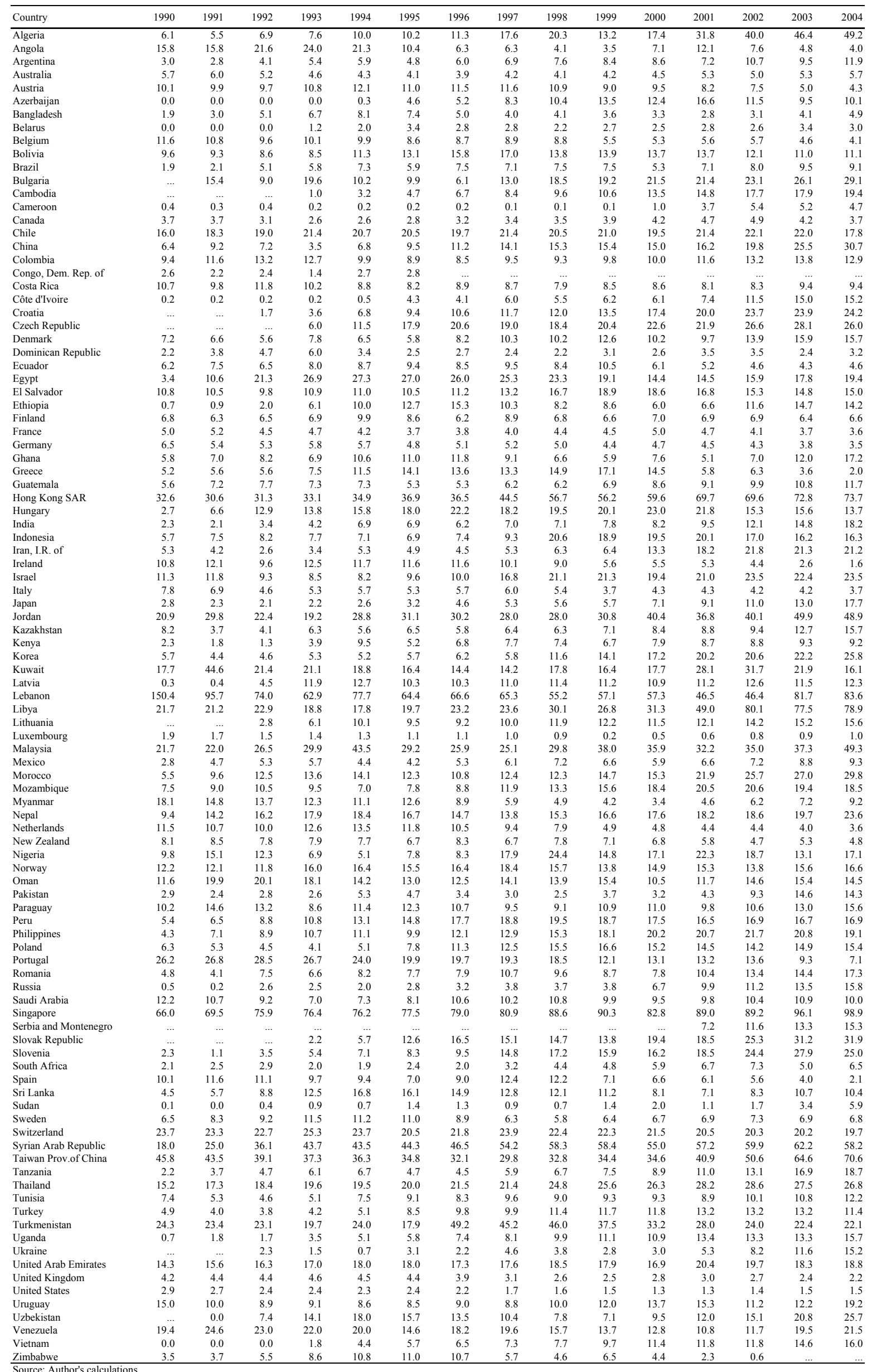


Table A4. Reserves in Months of Imports

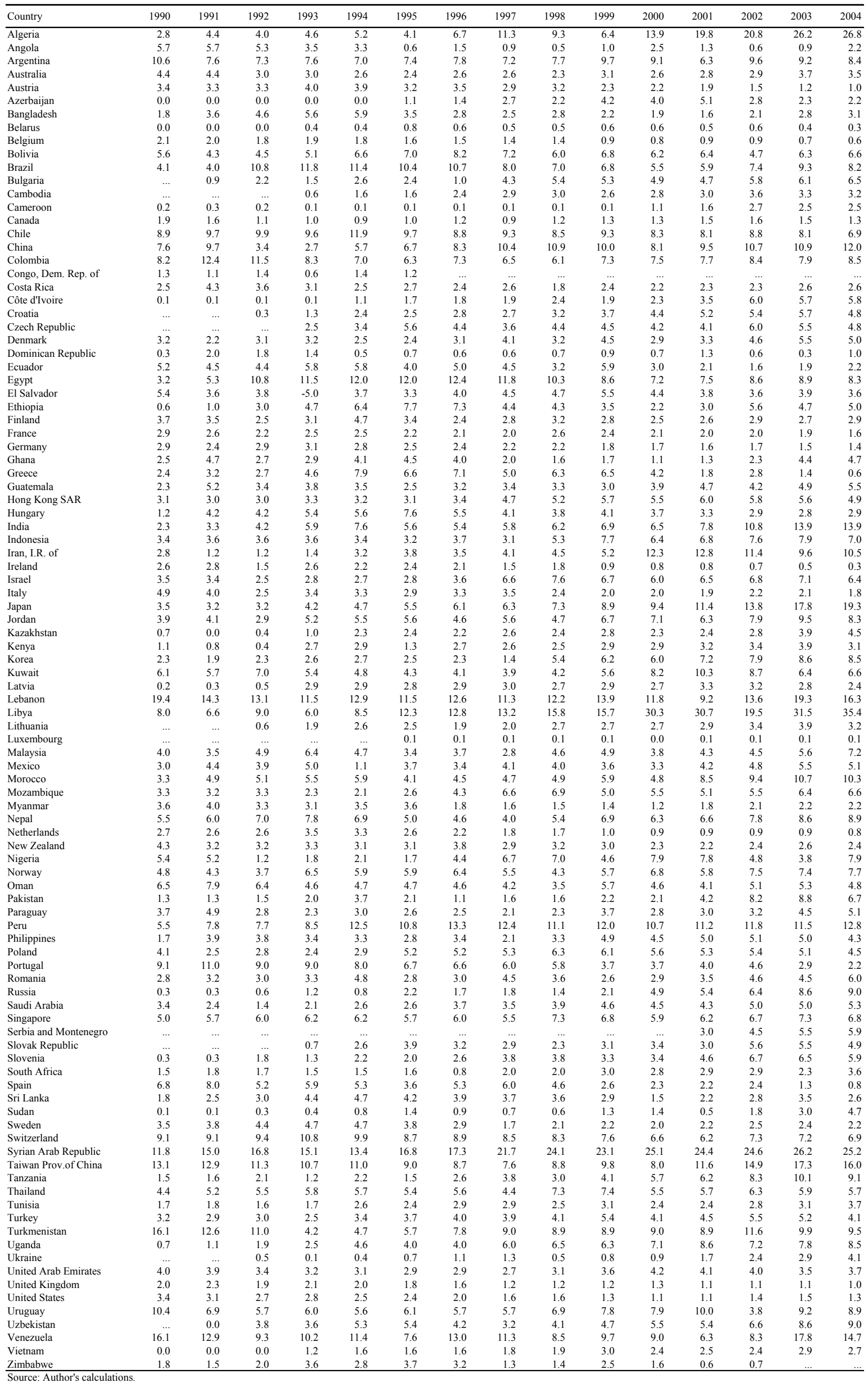


Figure A1. Spreads and Reserves, 1998-2004

(End-month total international reserves in US\$ billion on $x$-axis, monthly average of EMBI Global spreads in basis points on $y$-axis)
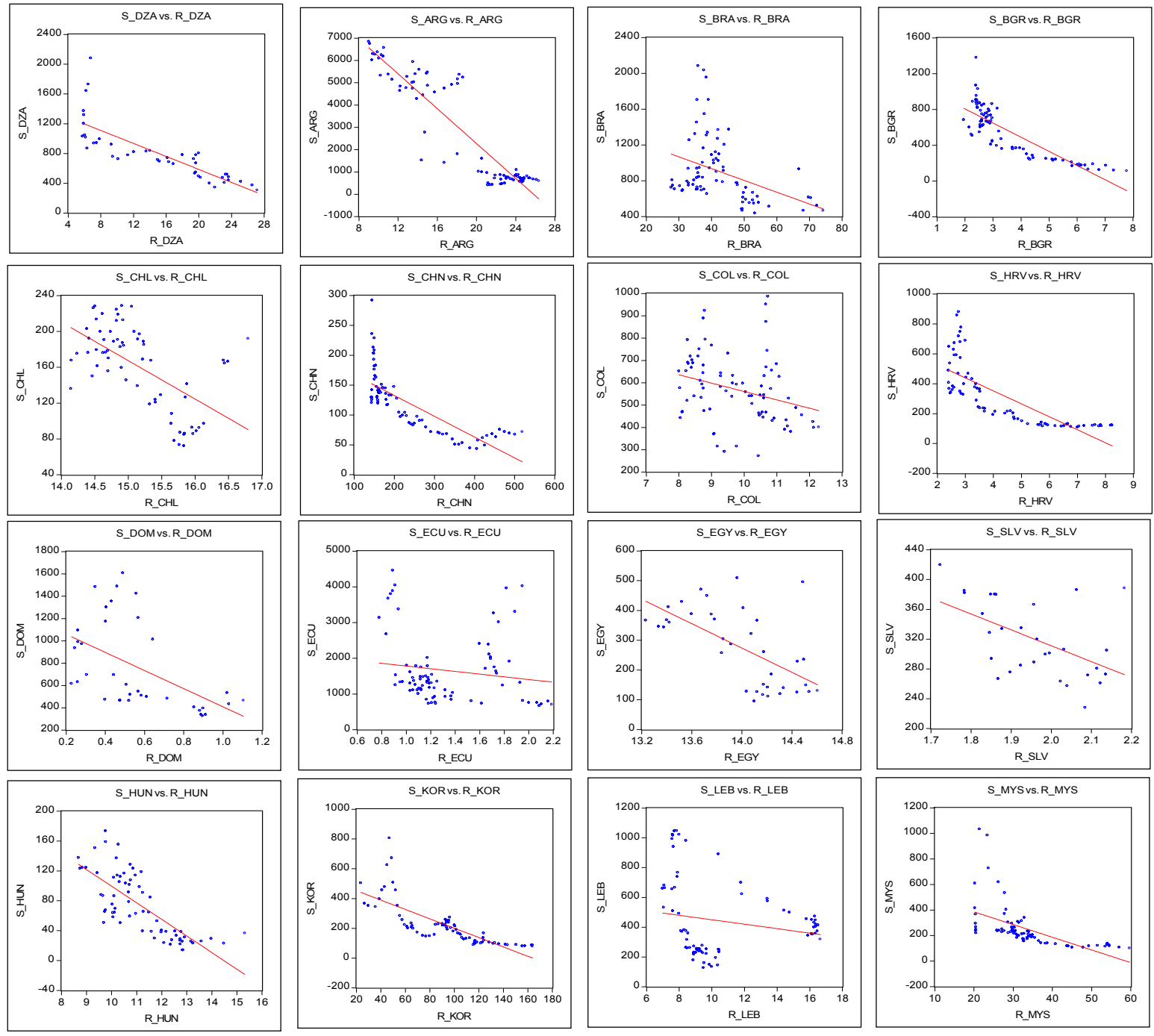
Figure A1. Spreads and Reserves, 1998-2004 (concluded) (End-month total international reserves in US\$ billion on $x$-axis, monthly average of EMBI Global spreads in basis points on $y$-axis)
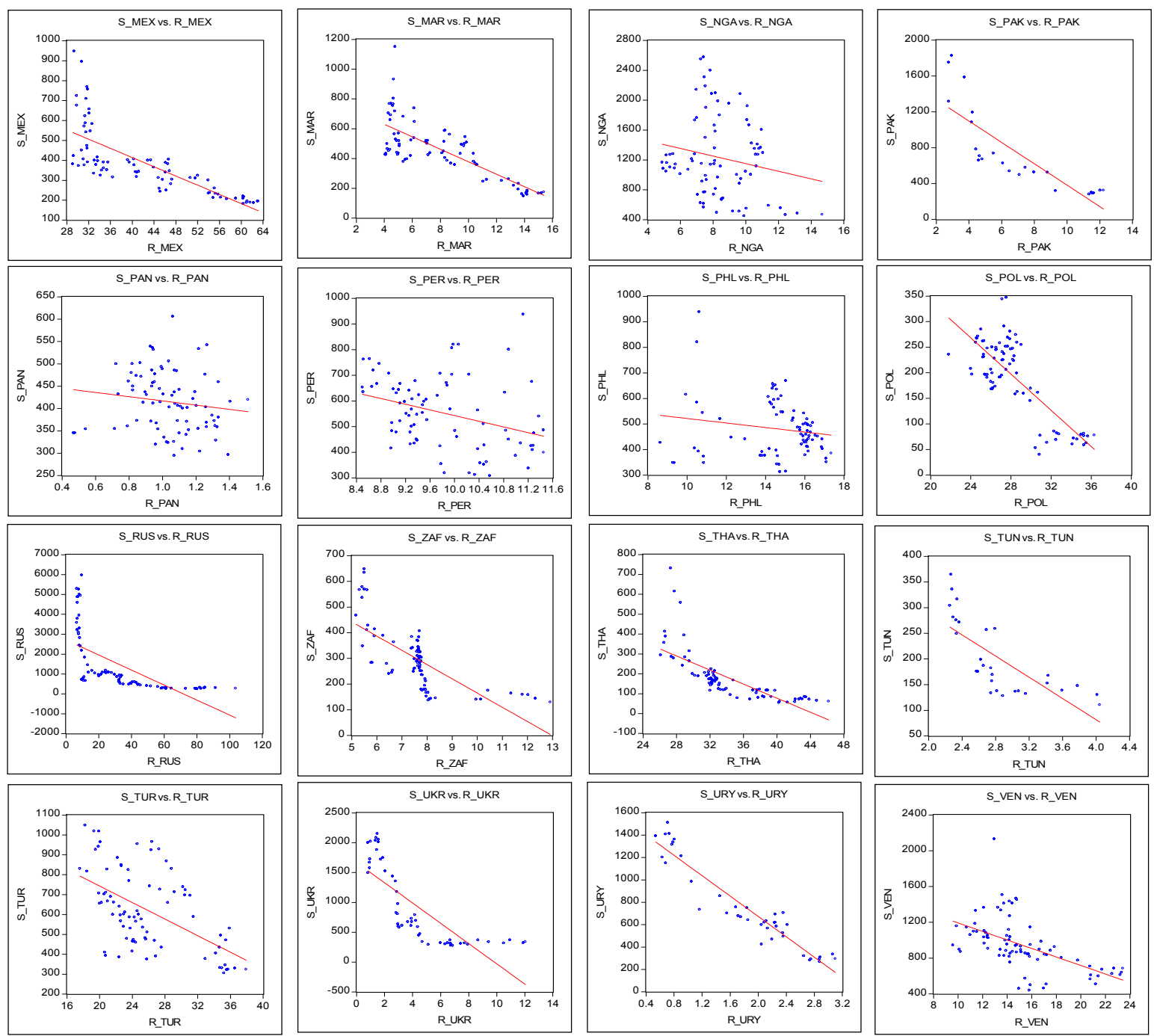

Sources: J.P. Morgan Chase \& Co. and IFS. 

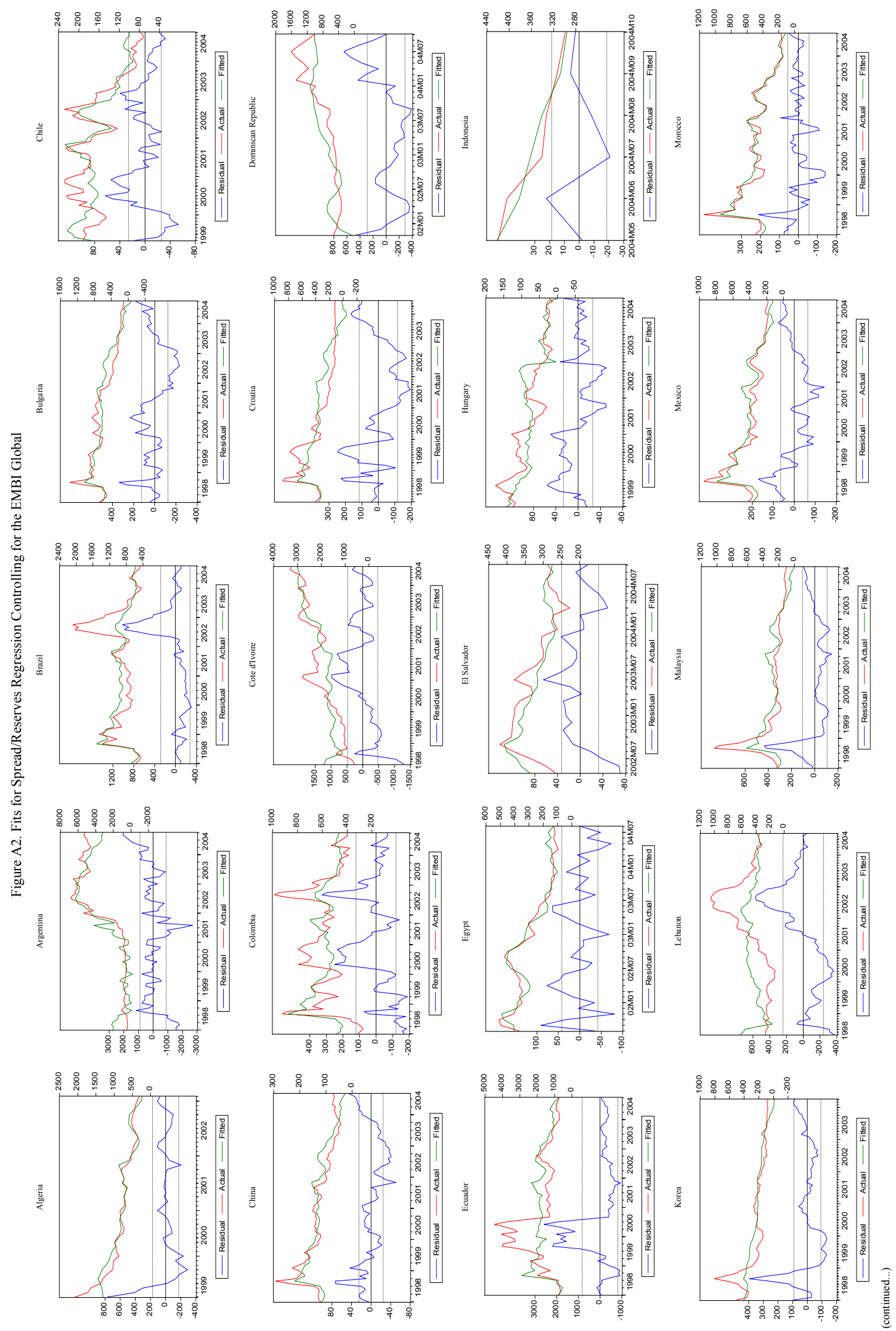

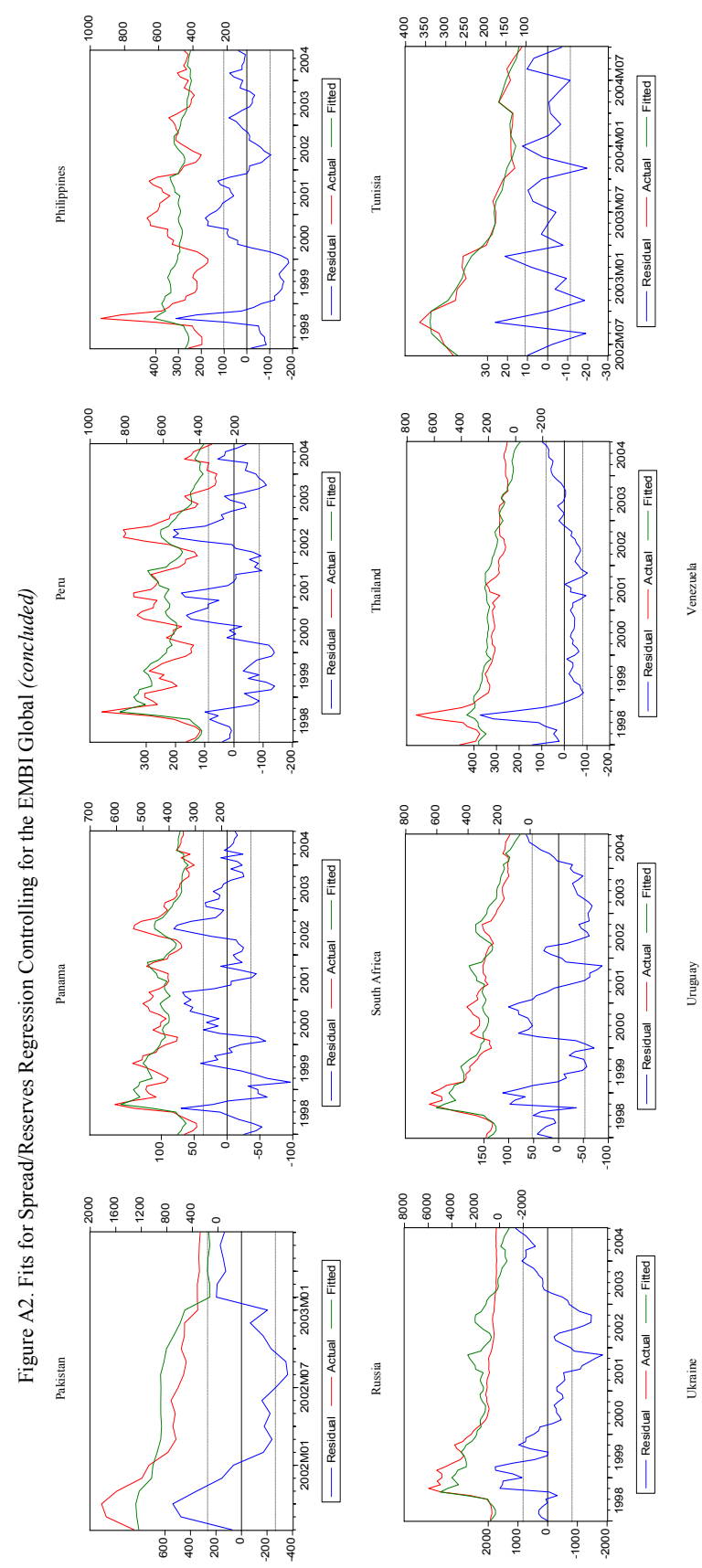

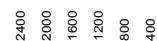
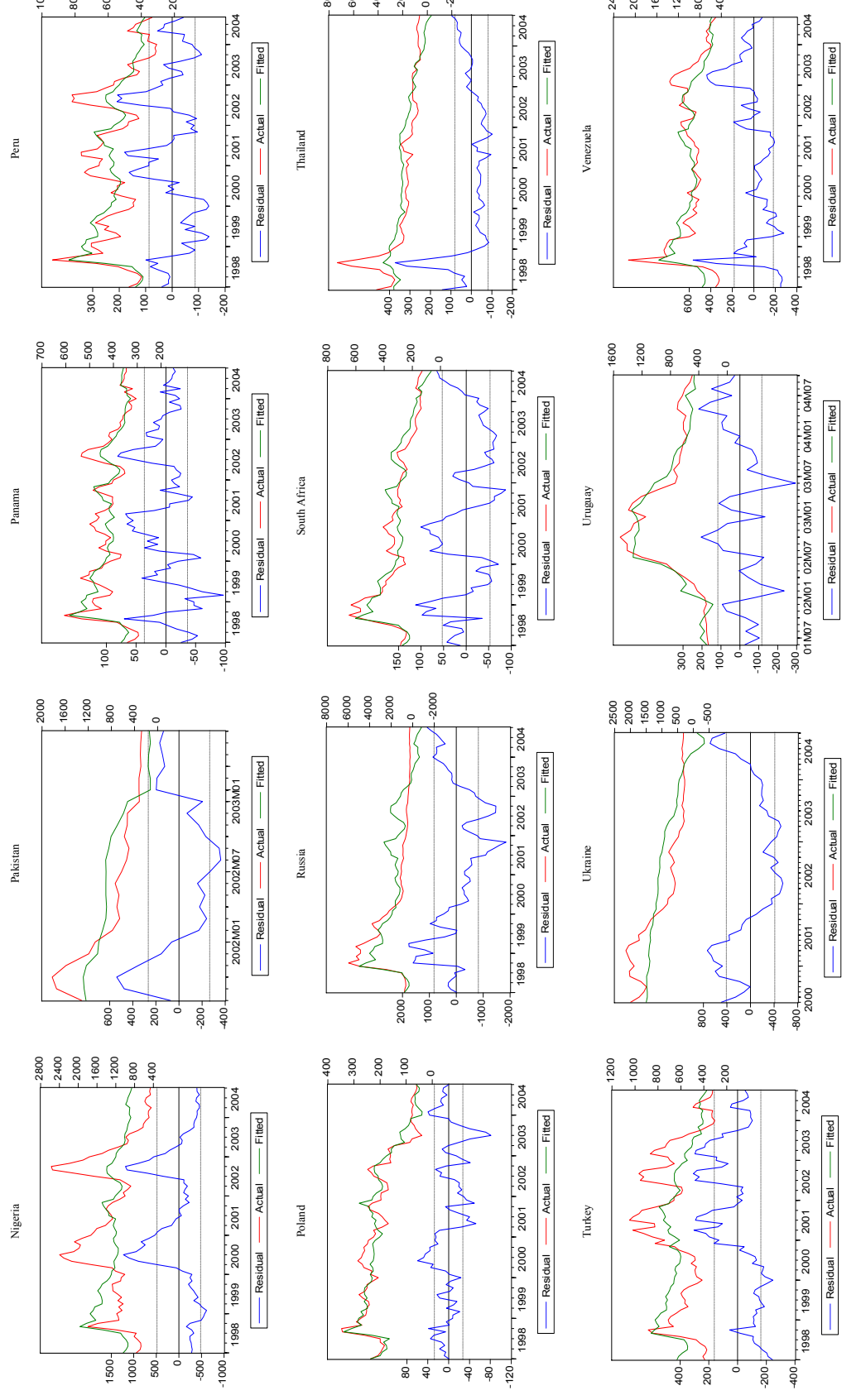


\section{REFERENCES}

Ben-Bassat, Avraham, and Daniel Gottlieb, 1992, "On the Effect of Opportunity Cost on International Reserve Holdings," The Review of Economics and Statistics (Vol. 74, No. 2), pp. 329-32.

Bird, Graham, and Ramkishen Rajan, 2003, "Too Much of A Good Thing? The Adequacy of International Reserves in the Aftermath of Crises," World Economy (Vol. 26, No. 6), pp. 873-91.

Clements, Benedict, Rina Bhattacharya, and Toan Quoc Nguyen, 2003, "External Debt, Public Investment, and Growth in Low-Income Countries," IMF Working Paper No. 03/249 (Washington: International Monetary Fund).

Duffie, Darrell, Lasse Heje Pedersen, and Kenneth J. Singleton, 2003, "Modeling Sovereign Yield Spreads: A Case Study of Russian Debt," The Journal of Finance (Vol. 63, No. 1), pp. 119-59.

Edison, Hali, 2003, “Are Foreign Exchange Reserves in Asia Too High?,” World Economic Outlook September 2003 (Washington: International Monetary Fund), pp. 78-92.

Edwards, Sebastian, 1985, "On the Interest-Rate Elasticity of the Demand for International Reserves: Some Evidence from Developing Countries," The Journal of International Money and Finance (Vol. 4, No. 3), pp. 287-95.

Eichengreen, Barry, and Ashoka Mody, 1998, "What Explains Changing Spreads on Emerging-Market Debt: Fundamentals or Market Sentiment?," NBER Working Paper No. 6408 (Cambridge, Massachusetts: National Bureau of Economic Research).

Flood, Robert, and Nancy Marion, 2002, "Holding International Reserves in an Era of High Capital Mobility,” IMF Working Paper No. 02/62 (Washington: International Monetary Fund).

Frenkel, Jacob A., and Boyan Jovanovich, 1981, "Optimal International Reserves: A Stochastic Framework," Economic Journal (Vol. 91, June), pp. 507-14.

Heller, H. Robert, 1966, “Optimal International Reserves”, Economic Journal (Vol. 76, June), pp. 296-311.

IMF, 2004a, "Accumulation of Reserves and Reliance on Local Markets," Global Financial Stability Report September 2004, pp. 141-59 (Washington: International Monetary Fund). , 2004b, "Public Investment and Fiscal Policy," available on the internet at http://www.imf.org/external/np/fad/2004/pifp/eng/pifp.pdf. 
Khan, Mohsin S., and Manmohan S. Kumar, 1997, "Public and Private Investment and the Growth Process in Developing Countries," Oxford Bulletin of Economics and Statistics (Vol. 59, No. 1), pp. 69-88.

Kletzer, Kenneth, and Mark M. Spiegel, 2000, "Sterilization costs and exchange rate targeting," unpublished (San Francisco: Federal Reserve Bank of San Francisco).

Landell-Mills, J.M., 1989, “The Demand for International Reserves and Their Opportunity Cost”, IMF Staff Papers (Vol. 36, No. 3), pp. 708-32.

Lee, Jaewoo, 2004, "Insurance Value of International Reserves: An Option Pricing Approach,” IMF Working Paper No. 04/175 (Washington: International Monetary Fund).

Nehru, Vikram, and Ashok Dhareshvar, 1995, A New Database on Physical Capital Stock (Washington: World Bank). 